\title{
Ectothiorhodospira halochloris sp. nov., a New Extremely Halophilic Phototrophic Bacterium Containing Bacteriochlorophyll $\mathrm{b}^{*}$
}

\author{
JOHANNES F. IMHOFF and HANS G. TRÜPER \\ Institut für Mikrobiologie der Universität Bonn, \\ Meckenheimer Allee 168, D-5300 Bonn, Federal Republic of Germany
}

\begin{abstract}
A new bacteriochlorophyll $b$ containing phototrophic bacterium was isolated from extremely saline and alkaline soda lakes in Egypt. Enrichment and isolation were performed using a synthetic medium with high contents of sodium carbonate, sodium sulfate and sodium chloride. Photoautotrophic growth occurred with hydrogen sulfide as photosynthetic electron donor. During oxidation of sulfide to sulfate extracellular elemental sulfur globules appeared in the medium. Cells were also capable to grow under photoheterotrophic conditions with acetate, propionate, pyruvate, succinate, fumarate or malate as carbon sources and electron donors. Under these conditions sulfate was assimilated. Optimal growth under the applied experimental conditions occurred at a total salinity of $14-27 \%$, a $\mathrm{pH}$-range between 8.1 and 9.1 and a temperature between $47^{\circ} \mathrm{C}$ and $50^{\circ} \mathrm{C}$. The cells were $0.5-0.6 \mu \mathrm{m}$ wide and, depending on cultural conditions, $2.5-8.0 \mu \mathrm{m}$ long; they were spiral shaped, multiplied by binary fission and were motile by means of bipolar flagella. Intercytoplasmic photosynthetic membranes were present as stacks. Bacteriochlorophyll $b$ was the main photosynthetic pigment; small amounts of carotenoids were mainly present as glucosides of rhodopin and its methoxy derivative. The new organism is described as Ectothiorhodospira halochloris.
\end{abstract}

Key words: Anaerobic phototrophic bacteria - Ectothiorhodospira halochloris - Halophilic bacteria Alkaliphilic bacteria - Sulfide oxidation - Bacteriochlorophyll $b$.

The first reports on phototrophic bacteria from concentrated brines were given by Baas Becking (1928) and van Niel (1931). Both described red colored spirilla,

\footnotetext{
* Dedicated to Professor C. B. van Niel on the occasion of his 80th birthday
}

and possibly these bacteria were identical with the later isolated Ectothiorhodopsora halophila (Raymond and Sistrom, 1967, 1969). In 1957 Jannasch made some enrichments with brine samples from a Wadi Natrun lake. He observed several red and green colored bacteria with sulfur globules inside the cells and also with deposition of elemental sulfur outside the cells, but he did not isolate them. Hence so far E. halophila was the only phototrophic bacterium isolated from an extreme saline environment and growing in media containing $9-30 \%$ sodium chloride.

During our present studies on the microbial ecology of the soda lakes in the Wadi Natrun, Egypt, we were able to isolate a second extremenly halophilic phototrophic bacterium. Several morphological and physiological properties of the new isolate justify to place it into the genus Ectothiorhodospira Pelsh and to describe it as the new species Ectothiorhodospira halochloris.

\section{MATERIAL AND METHODS}

\section{Media for Enrichment and Isolation}

Based upon data from Jannasch (1957) about the ionic composition of a lake in the Wadi Natrun, for enrichment cultures and isolation procedures the following medium was composed: $1 \mathrm{ml}$ trace element solution ("SLA"), $1 \mathrm{ml}$ vitamin solution ("VA"), $0.05 \mathrm{~g}$ $\mathrm{CaCl}_{2} \cdot 2 \mathrm{H}_{2} \mathrm{O}, 0.5 \mathrm{~g} \mathrm{KH}_{2} \mathrm{PO}_{4}, 0.8 \mathrm{~g} \mathrm{NH} 4 \mathrm{Cl}, 0.1 \mathrm{~g} \mathrm{MgCl}_{2} \cdot 6 \mathrm{H}_{2} \mathrm{O}$, $180 \mathrm{~g} \mathrm{NaCl}, 20 \mathrm{~g} \mathrm{Na}_{2} \mathrm{SO}_{4}, 20 \mathrm{~g} \mathrm{Na}_{2} \mathrm{CO}_{3}$ were dissolved in 11 of distilled water. As supplements to this basal growth medium $0.05 \%$ yeast extract, $0.1 \%$ sodium succinate and $0.1 \% \mathrm{Na}_{2} \mathrm{~S} \cdot 9 \mathrm{H}_{2} \mathrm{O}$ were added. For the isolation initial $\mathrm{pH}$ was adjusted to 9.6 , later on to 8.5 . In the first enrichment cultures the total salinity was $35 \%$.

Trace Element Solution. $1.8 \mathrm{~g} \mathrm{FeCl}_{2} \cdot 4 \mathrm{H}_{2} \mathrm{O}, 250 \mathrm{mg} \mathrm{CoCl} \cdot 6 \mathrm{H}_{2} \mathrm{O}$, $10 \mathrm{mg} \mathrm{NiCl} \cdot 6 \mathrm{H}_{2} \mathrm{O}, 10 \mathrm{mg} \mathrm{CuCl} \cdot 2 \mathrm{H}_{2} \mathrm{O}, 70 \mathrm{mg} \mathrm{MnCl} 2 \cdot 4 \mathrm{H}_{2} \mathrm{O}$, $100 \mathrm{mg} \mathrm{ZnCl}$, $500 \mathrm{mg} \mathrm{H}_{3} \mathrm{BO}_{3}, 30 \mathrm{mg} \mathrm{Na} \mathrm{MoO}_{4} \cdot 2 \mathrm{H}_{2} \mathrm{O}$ and $10 \mathrm{mg} \mathrm{Na} \mathrm{SeO}_{3} \cdot 5 \mathrm{H}_{2} \mathrm{O}$ were dissolved in 11 of bidistilled water.

Vitamin Solution. $10 \mathrm{mg}$ biotin, $35 \mathrm{mg}$ nicotinamide, $30 \mathrm{mg}$ thiamine dichloride, $20 \mathrm{mg}$ p-aminobenzoic acid, $10 \mathrm{mg}$ pyridoxal chloride, $10 \mathrm{mg}$ Ca-pantothenate and $5 \mathrm{mg}$ vitamin $\mathrm{B}_{12}$ were dissolved in $100 \mathrm{ml}$ bidistilled water. 


\section{Isolation}

Ectothiorhodospira halochloris was isolated by repeated agar shake dilution according to Pfennig (1965). The procedure was performed using the described medium and a final agar concentration of $0.6 \%$. In sulfide free media anaerobic conditions were obtained by the addition of $0.05 \%$ sodium ascorbate. Test tubes were incubated at $30^{\circ} \mathrm{C}$ and illuminated with a light intensity of about 1000 lux. After purity was achieved one single colony was transferred into liquid culture medium and grown under the same conditions.

\section{Growth Experiments}

For the determination of the $\mathrm{pH}$ optima a salinity of the medium of $25 \%$ was used. The ratio of $\mathrm{Na}_{2} \mathrm{CO}_{3}$ to $\mathrm{NaHCO}_{3}$ was varied to obtain the right $\mathrm{pH}$-values; if necessary the $\mathrm{pH}$ was adjusted with $\mathrm{NaOH}$ or $\mathrm{H}_{2} \mathrm{SO}_{4}$. Salt optima were determined at $\mathrm{pH} 8.5$ with a constant ratio of $\mathrm{NaCl} / \mathrm{Na}_{2} \mathrm{CO}_{3} / \mathrm{Na}_{2} \mathrm{SO}_{4}=8 / 1 / 1(\mathrm{w} / \mathrm{w} / \mathrm{w})$. In all experiments growth was followed at least over three passages in the same medium. To examine the utilization of carbon, sulfur and nitrogen compounds two parallels were inoculated for each substrate. The temperature optimum was measured in a temperature controlled light-fermentation vessel with optimal $\mathrm{pH}$-value and salt concentration. This experiment was started at $30^{\circ} \mathrm{C}$ and the temperature was than stepwise increased to $55^{\circ} \mathrm{C}$ using an appreciable amount of the previous culture as inoculum for the next step. Growth was measured as counts of total cells.

\section{Preparation of Cells for Light and Electron Microscopy}

For photomicrographs a $2 \%$ solution of washed agar was distributed in $2 \mathrm{ml}$ portions on sildes and completely dried. In order to achieve that cells were properly fixed between agar and cover glass, but not squeezed different volumes of cell suspensions were used $(5-15 \mu \mathrm{l})$. For electron micrographs cells were sedimented on a pioloform $F$ coated copper slide, stained with a $2 \%$ solution of phosphotungstic acid with the addition of $0.1 \%$ glycerol (pH 6.7). All electron micrographs were taken with a Phillips EM 200 electron microscope.

\section{Characterization of Photosynthetic Pigments}

Absorption spectra were measured with a Zeiss DMR 21 and a Perkin Elmer 124 spectrophotometer. Extraction of bacteriochlorophylls and separation on silicagel was done as described by Gloe et al. (1975). The identification of the bacteriochlorophyll was carried out by cochromatography of the bacteriopheophytins of E. halochloris strain BN 9850, Rhodopseudomonas viridis strain BN 170 and Rhodospirillum rubrum strain $\mathrm{Ha}$; the absorption spectrum of the separated bacteriopheophytin was measured. Carotenoid extraction and identification was done in the usual manner (Jensen, 1962; Hager and Stransky, 1970).

\section{Determination of DNA Base Composition}

Deoxyribonucleic acid was isolated after Meyer and Schleifer (1975) using cetyltrimethylammoniumbromide (CTAB) for the precipitation. Purity was checked spectroscopically after Ulitzur (1972). If necessary an additional precipitation step with isopropanol was carried out. The base ratio expressed as moles- $\%$ guanine plus cytosine was calculated from the melting temperature according to Marmur and Doty (1962); this work was kindly done by Dr. H. Hippe (Göttingen).

\section{RESULTS}

\section{Natural Habitat and Isolation}

Ectothiorhodospira halochloris is living in several extremely saline lakes of the Wadi Natrun (Egypt). This location is a depression in the Libyan Desert with several lakes, which contain concentrated brines with total salinities of up to $40 \%$. In most of the lakes a layer of crystalline salt deposits exists. High concentrations of sulfate and organic matter in the sediments and the mud surrounding the lakes favor the development of sulfate-reducing bacteria and lead to the evolution of considerable amounts of hydrogen sulfide and carbon dioxide (Abd el Malek and Rizk, 1963). With its high salinities, $\mathrm{pH}$-values of about 11.0, and anaerobic conditions due to its content of hydrogen sulfide, this environment has unique properties.

Using a medium with high contents of sodium carbonate, sodium sulfate and sodium chloride $E$. halochloris was isolated from mud and water sam les of several pools in the Wadi Natrun. Agar shake dilution series inoculated with water from small pools or water from the sediment-water interface of the lakes Abu Gabara, Zugm, Hamra, Gaar, Muluk and Rizunia yielded $10^{8}$ to $10^{9}$ viable cells per liter of both E. halochloris and E. halophila. Probably E. halochloris is very common in environments similar to the investigated lakes of the Wadi Natrun.

\section{Morphology}

Cells of E. halochloris are spiral shaped (Figs. 1 and 2) and usually show one or two complete turns under favorable conditions. One complete turn measures $3.5-5.0 \mu \mathrm{m}$. Whole cells are $0.5-0.6 \mu \mathrm{m}$ wide and depending on cultural conditions $-2.5-8.0 \mu \mathrm{m}$ long, under unfavorable conditions even $15 \mu \mathrm{m}$ or more. E. halochloris is bipolarly flagellated possessing two or three flagella at each cellular pole (Fig. 2). Cell division occurred by binary fission. Intracytoplasmic membranes occur as stacks (Figs. 2 and 3 ) as in the brown colored Rhodospirillum species, $R$. fulvum, $R$. molischianum, R.photometricum (Gibbs et al., 1965) and the species of the genus Ectothiorhodospira, E. shaposhnikovii (Cherni et al., 1969), E. mobilis (Trüper, 1968; Remsen et al., 1968; Holt et al., 1968) and $E$. halophila (Raymond and Sistrom, 1967, 1969). The stacks can be observed under high magnification with the light microscope as areas of stronger light absorption, in pressed cells even as dark inclusions. Negative stains viewed with the electron microscope revealed a more detailed structure. Cells grown with light intensities below 1000 lux were almost filled up with stacks, which appeared as spherical bodies under low magnification. One single stack is composed 


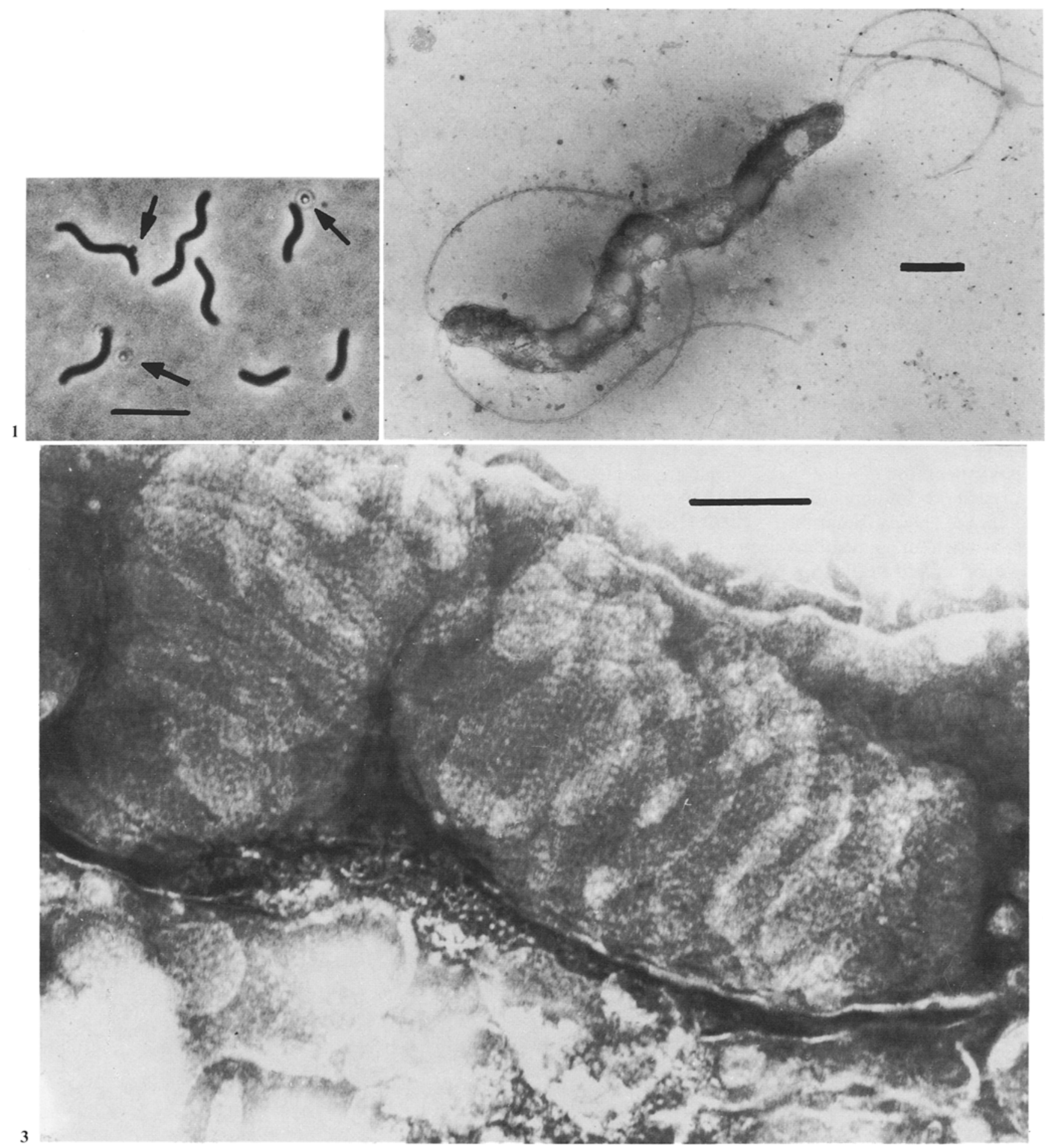

Fig. 1. Phase contrast photomicrogtaph of Ectothiorhodospira halochloris strain BN 9850 grown autotrophically on sulfide as electron donor. Arrow's indicate globules of elemental sulfur. Bar indicates $5 \mu \mathrm{m}$

Fig. 2. Electron micrograph of a negatively stained cell of Ectothiorhodospira halochloris strain BN 9850 nearly filled up with membrane stacks. The cell is fixed in liquid medium in a phase of active movement. Bar indicates $1.0 \mu \mathrm{m}$

Fig. 3. Top view of two membrane stacks within a negatively stained cell of Ectothiorhodospira halochloris strain BN 9850 , revealing a granulated surface structure of the membranes with an average diameter of the granules of about $10 \mathrm{~nm}$. Bar indicates $200 \mathrm{~nm}$ 


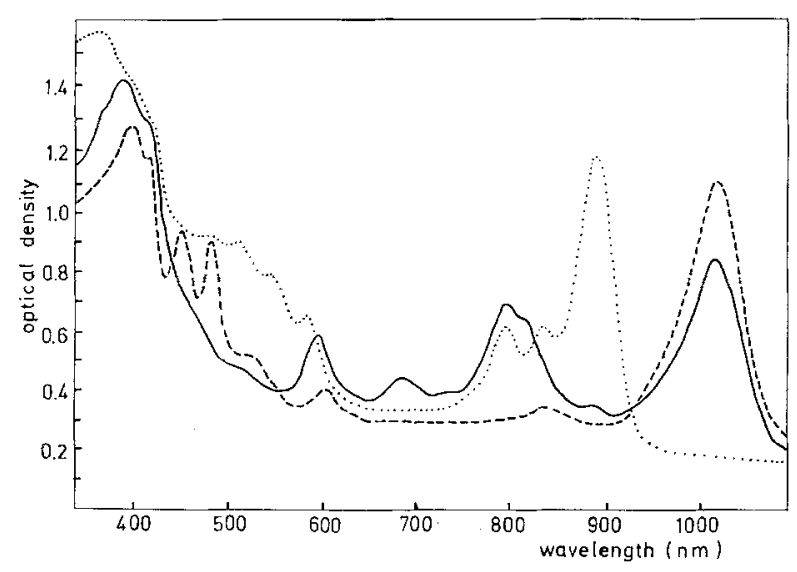

Fig. 4. Absorption spectra of chromatophore suspensions of Ectothiorhodospira halochloris strain BN $9850(-)$, Ectothiorhodospira halophila strain BN 9910 (------) and Rhodopseudomonas sulfoviridis strain $\mathrm{P}_{1}(---)$

of several flat membrane discs, which are connected with each other and possibly also with the cytoplasmic membrane as was found in E. mobilis (Remsen et al., 1968). High magnification electron micrographs of negatively stained cells showed a regularly granulated structure of the membrane surfaces, with an average granule diameter of about $10 \mathrm{~nm}$ (Fig. 3). The same structure was also seen in cell free fractions of isolated chromatophores of E. halochloris.

\section{Photosynthetic Pigments}

Young cultures of E. halochloris have a pale green color like that of gooseberry fruits, whereas dense populations get a brownish shade. The absorption maxima at 389,598 and $1018 \mathrm{~nm}$ of whole cells and cell free suspensions indicate the presence of bacteriochlorophyll $b$ (see Fig. 4). In addition peaks at 374, 796 , and $884 \mathrm{~nm}$ occur, which were not observed in cell free suspensions of Rps. viridis and Rps. sulfoviridis; they are present in extracts of E. halophila (Fig. 4) and the other phototrophic bacteria with bacteriochlorophyll $a$ as the main photosynthetic pigment. Therefore, the presence of a second bacteriochlorophyll is suggested. This may be bacteriochlorophyll $a$ or a very similar compound. In Rps. viridis and Rps. sulfoviridis (Fig. 4), which show almost identical spectra and also in Thiocapsa pfennigii (Eimhjellen et al., 1967) the maxima of bacteriochlorophyll $b$ appear at 398,602 , and $1020 \mathrm{~nm}$. The slight shift of the absorption maxima to shorter wavelength in E. halochloris is possibly due to the presence of the second bacteriochlorophyll compound. Cochromatography of the extracted bacteriopheophytins of E. halochloris and Rps. viridis showed identical $R_{f}$-values. The brown color of the bacterio- pheophytin $b$ was clearly visible. Though bacteriopheophytin $a$ has nearly the same $R_{f}$-value, it is easily distinguishable from bacteriopheophytin $b$ by its intensive violet color. We did not find bacteriopheophytin $a$ in the chromatograms of E. halochloris extracts. The purified bacteriopheophytin $b$ from $E$. halochloris showed absorption maxima at 368,399 , $526,619,628$, and $775 \mathrm{~nm}$ in acetone. The same spectrum was reported for the bacteriopheophytins of Rps. viridis (Drews and Giesbrecht, 1965; Gloe, unpublished results) and Thiocapsa pfenigii (Eimhjellen et al., 1967).

As the in vivo absorption maxima between 450 and $550 \mathrm{~nm}$ are rather low (Fig. 4), the total carotenoid content is low compared to that of the other phototrophic bacteria. According to preliminary results (K. Schmidt, personal communication) the major carotenoids of $E$. halochloris are glucosides of rhodopin $(20 \%)$ and its methoxy derivative $(60 \%)$. About $10 \%$ of each rhodopin and lycopene are present as free carotenoids.

\section{Optimal Growth Conditions}

E. halochloris is an extremely halophilic bacterium. It shows adaptation to a wide range of different salt concentrations, even if growing very slowly at the extremes. This broad salt optimum is presented in Figure 5: More than $50 \%$ of the optimal growth yield, expressed as optical density at $650 \mathrm{~nm}$, occurred between $10 \%$ and $34 \%$ total salinity and more than $90 \%$ between $14 \%$ and $27 \%$; optimum salinity was $20 \%$.

Best growth was observed at $\mathrm{pH} 8.5$; more than $50 \%$ of the maximum growth yield was obtained between pH 7.5 and 10.0 and more than $90 \%$ between 8.1 and 9.1 (Fig. 6).

$E$. halochloris is slightly thermophilic. Below $33^{\circ} \mathrm{C}$ growth was very slow with a generation time of $30 \mathrm{~h}$ at $30^{\circ} \mathrm{C}$. From $33-50^{\circ} \mathrm{C}$ a slow decrease in the generation time from $20 \mathrm{~h}$ to $10 \mathrm{~h}$ was observed (Fig. 7). Best growth occurred between $47^{\circ} \mathrm{C}$ and $50^{\circ} \mathrm{C}$ with generation times of 10.9 and $10.0 \mathrm{~h}$, respectively. At $50^{\circ} \mathrm{C}$ cells became unusually thick, and further increase of temperature led to lysis of the cells.

\section{Physiology}

E. halochloris is able to grow under anaerobic, photolithoautotrophic conditions with hydrogen sulfide as electron donor and carbon dioxide as sole carbon source. Under these conditions sulfide is first oxidized to extracellular elemental sulfur, which is further oxidized to sulfate when sulfide becomes depleted. Globules of elemental sulfur appeared in the medium, some- 

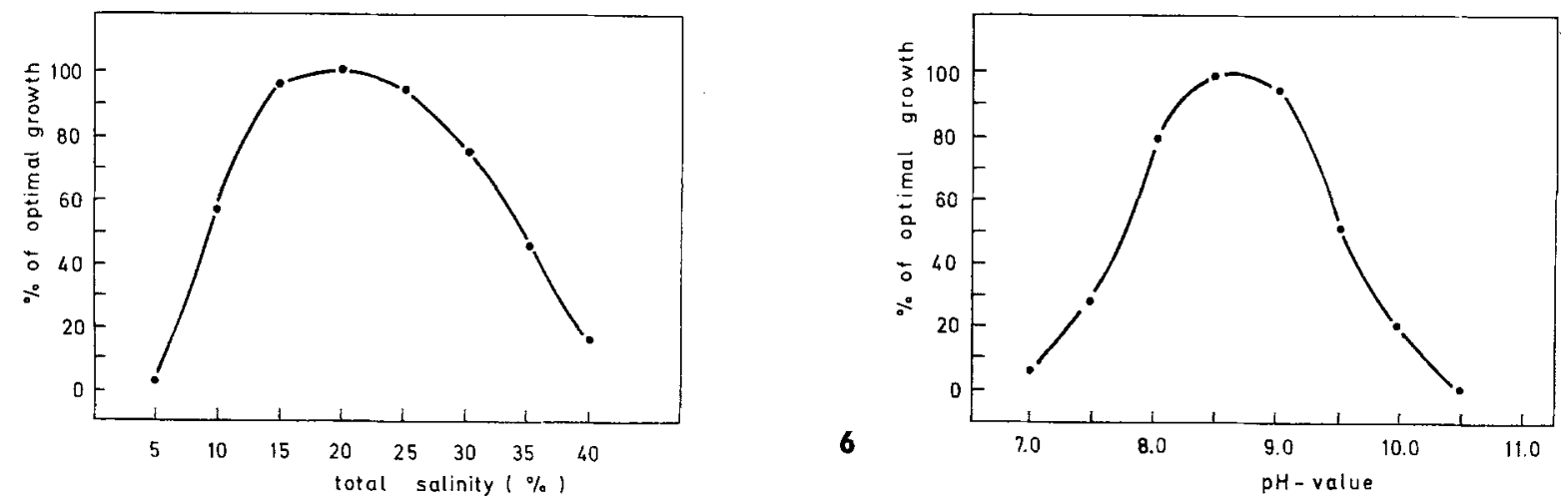

Fig. 5. Salt optimum graph of Ectothiorhodospira halochloris strain BN 9850; each point represents the average value of four succeeding passages; growth was measured as optical density at $650 \mathrm{~nm}$

Fig. 6. pH optimum graph of Ectothiorhodospira halochloris strain BN 9850. Each point represents the average value of three succeeding passages at the same $\mathrm{pH}$; growth was measured as optical density at $650 \mathrm{~nm}$

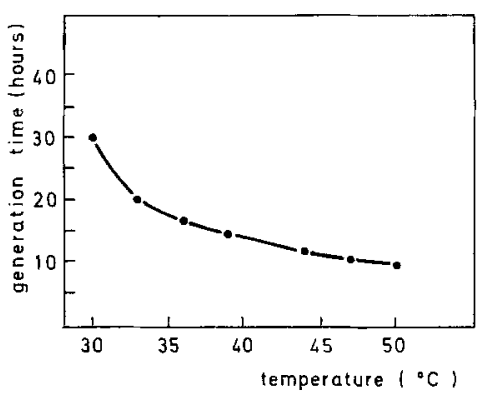

Fig. 7. Temperature dependence of the generation time of Ectothiorhodospira halochloris strain BN 9850 ; above $50^{\circ} \mathrm{C}$ no growth was obtained

times closely attached to the cells, but were never observed inside the cells (Fig. 1). More abundant growth occurred under photoheterotrophic conditions with acetate, propionate, pyruvate, succinate, malate or fumarate as electron donor and carbon source; reducing conditions were provided by the addition of $0.05 \%$ sodium ascorbate. In addition to the above mentioned electron donors, casamino acids supported growth in the presence of sulfide and carbonate; sugars, sugar alcohols and higher fatty acids as well as citrate, lactate and formate were not used (Table 1). Without carbonate growth did not occur with any of the substrates tested. No measurable growth was obtained under aerobic or anaerobic conditions in the dark. Microaerophilic growth of E. halochloris was observed in agar shake cultures in the light. Good growth occurred with ammonia or glutamine as nitrogen source; nitrate, nitrite, urea, glutamate and asparagine were not utilized. E. halochloris was capable of assimilatory sulfate reduction and growth with sulfate, thiosulfate, elemental sulfur, cysteine or sulfide as sulfur source was possible.
Table 1. Utilization of organic carbon sources by Ectothiorhodospira halochloris, strain BN 9850 in mineral salts medium with $0.1 \%$ sodium sulfide

\begin{tabular}{llllll}
\hline fructose & - & propanol & - & malate & + \\
glucose & - & acetate & ++ & propionate & ++ \\
saccharose & - & fumarate & + & butyrate & - \\
sorbose & - & succinate & + & valerate & - \\
galactose & - & pyruvate & ++ & caproate & - \\
mannitol & - & citrate & - & caprylate & - \\
sorbitol & - & tartrate & - & pelargonate & - \\
glycerol & - & ascorbate & - & benzoate & - \\
methanol & - & casamino & & lactate & - \\
ethanol & - & acids & + & formate & - \\
\hline
\end{tabular}

$-=$ Growth as in the control without added substrate; $+=$ additional growth, OD at $650 \mathrm{~nm}$ below $0.3 ;++=$ additional growth, OD at $650 \mathrm{~nm} 0.3$ to 0.9

Final substrate concentration $0.1 \%$ in the first and second and $0.05 \%$ in the third column

\section{DISCUSSION}

Thus far only three species of phototrophic bacteria containing bacteriochlorophyll $b$ have been described, namely Rhodopseudomonas viridis (Drews and Giesbrecht, 1966), Rhodopseudomonas sulfoviridis (Keppen and Gorlenko, 1975) and Thiocapsa pfennigii (Eimhjellen et al., 1967; Eimhjellen, 1970). They all differ in cell shape and structure of the intracytoplasmic membranes from the new isolate. While Rps. viridis and Rps. sulfoviridis are small rods multiplying by budding and possessing photosynthetic membranes underlying the cytoplasmic membranes (Drews and Giesbrecht, 1965, 1966; Whittenbury and McLee, 1967; Keppen and Gorlenko, 1975), Thiocapsa pfennigii is a coccus with tubular intracytoplasmic membranes (Eimhjellen et al., 1967).

E. halochloris has spiral shaped cells and possesses several distinct membrane stacks carrying the photo- 
Table 2

Comparison of the major characteristics of Ectothiorhodospira halochloris with those of the other species of the genus Ectothiorhodospira

\begin{tabular}{|c|c|c|c|c|}
\hline & E. halochloris & E. halophila & E. mobilis ${ }^{\mathrm{a}}$ & E. shaposhnikovii ${ }^{\mathbf{a}}$ \\
\hline Cell shape & spiral & spiral & spiral & spiral \\
\hline Cell diameter & $0.5-0.6 \mu \mathrm{m}$ & $0.8 \mu \mathrm{m}$ & $0.7-1.0 \mu \mathrm{m}$ & $0.8-0.9 \mu \mathrm{m}$ \\
\hline Flagellation & bipolar & bipolar & polar tuft & polar tuft \\
\hline Internal membrane system & stacks & stacks & stacks & stacks \\
\hline bchl & $\mathrm{b}(\mathrm{a})$ & $\mathrm{a}$ & $\mathrm{a}$ & $\mathrm{a}$ \\
\hline Major carotenoid & rhodopin ${ }^{b}$ & spirilloxanthin & spirilloxanthin & spirilloxanthin \\
\hline Rhodopin content ${ }^{c}$ & about 90 & $<1.0$ & $10-20$ & $10-20$ \\
\hline Optimal pH & $8.1-9.1$ & $7.4-7.9$ & $7.6-8.0$ & $8.0-8.5$ \\
\hline Optimal salinity & $14-27 \%$ & $11-22 \%$ & $2-3 \%$ & $<1 \%$ \\
\hline Optimal temperature & $48^{\circ} \mathrm{C}$ & $47^{\circ} \mathrm{C}$ & $25-29^{\circ} \mathrm{C}$ & $30-35^{\circ} \mathrm{C}$ \\
\hline Sulfate assimilated & + & - & + & + \\
\hline Sulfide oxidized & + & + & + & + \\
\hline Extracellular sulfur formed & + & + & + & + \\
\hline DNA-base ratio & 52.9 & 68.4 & $67.3-69.9$ & $61.2-62.8$ \\
\hline
\end{tabular}

a References in the text

b Present as rhodopin, rhodopin glucoside and methoxy rhodopin glucoside

c Values in $\%$ of the total carotenoid content

synthetic pigments; in this respect it closely resembles the species of the genus Ectothiorhodospira and the brown colored Rhodospirillum species, but differs from the bacteriochlorophyll $b$ containing bacteria mentioned above.

The growth of Rps. viridis, belonging to the Rhodospirillaceae is suppressed by rather low concentrations of sulfide (Drews and Giesbrecht, 1966). Rps. sulfoviridis differs from Rps. viridis by its obligate dependence on reduced sulfur compounds such as sulfide or cysteine (Keppen and Gorlenko, 1975). Thiocapsa pfennigii on the other hand belongs to the Chromatiaceae. Growing with sulfide as electron donor and sole sulfur source it accumulates elemental sulfur inside the cells (Eimhjellen et al., 1967).

E. halochloris deposits elemental sulfur outside the cells as is characteristic for the genus Ectothiorhodospira and the phototrophic green bacteria. The latter, however, differ markedly in structure and pigment content from the phototrophic purple bacteria (Pfennig and Trüper, 1974). Cell shape, fine structure and the pattern of sulfide oxidation together justify the allocation of the new species within the genus Ectothiorhodospira.

Within the genus Ectothiorhodospira, E. halochloris is characterized by the possession of bacteriochlorophyll $b$ while the other species contain bacteriochlorophyll $a$ as the main photosynthetic pigment. E. mobilis, $E$. shaposhnikovii and E. halophila have similar proportions of carotenoids of the spirilloxanthin series with spirilloxanthin as the main component (Schmidt and Trüper, 1971). E. halochloris possesses only small amounts of carotenoids; mainly glucosides of rhodopin and its methoxy derivative are present. The situation is comparable to that between Rps. viridis and Rps.palustris; both show similar cell shape and fine structure, but Rps. viridis possesses bacteriochlorophyll $b$ and Rps. palustris bacteriochlorophyll $a$. They also have different carotenoids.

Optimal growth conditions of E. halochloris differ from those of the other species; they are most similar to the growth conditions of E. halophila. A summary of some characteristic properties of the Ectothiorhodospira species is given in Table 2. E. halochloris shows a requirement for high amounts of salts and does not grow with less than $10 \%$ total salts. The same requirement is reported for E. halophila by Raymond and Sistrom (1967); E. mobilis needs only $2-3 \%$ sodium chloride (Trüper, 1968) and E. shaposhnikovii has no requirement for sodium chloride. As is shown in Table 2, the optimal $\mathrm{pH}$-range is more alkaline for E. halochloris and the temperature optimum is as high as for $E$. halophila, being about $47-48^{\circ} \mathrm{C}$. The extreme growth conditions together with morphological observations and characteristic absorption spectra of living cells allow a relatively easy recognition of $E$. halochloris.

\section{SPECIES DESCRIPTION}

Ectothiorhodospira halochloris sp.nov. ha.lo.chlo'ris. hals Gr.n. salt, chloros Gr. adj. green, halochloris M. L. adj. green colored and salt loving.

Morphology. Cells spiral shaped. Width $0.5-0.6 \mu \mathrm{m}$; length depending on cultural conditions, normally $2.5-8.0 \mu \mathrm{m}$. Motile by means of bipolar flagella. Multiplying by binary fission. Intracytoplasmic membranes present as large lamellar stacks. 
Culture. Phototrophic growth under anaerobic conditions; photoautotrophic and photoheterotrophic growth is possible. Optimal pH-range 8.1-9.1. Optimal salinity $14-27 \%$ total salts, no growth below $10 \%$. Optimal growth temperature $48^{\circ} \mathrm{C}$. Color of cell suspensions pale green to green, in dense populations with a brownish shade. In solid media green lensshaped colonies are formed. If grown on sulfide, young colonies are surrounded by a whitish halo of elemental sulfur, which dissappears during further growth. $\mathrm{Ca}$ pable of assimilatory sulfate reduction.

Photosynthetic Pigments. Bacteriochlorophyll $b$ is the main photosynthetic pigment. Small amounts of carotenoids are present mainly as glucosides of rhodopin and its methoxy derivative. Maxima of in vivo absorption spectra at 374,796 , and $884 \mathrm{~nm}$ indicate the presence of a second bacteriochlorophyll compound, which may be similar or identical with bacteriochlorophyll $a$.

Photosynthetic Electron Donors. Sulfide, elemental sulfur, acetate, propionate, pyruvate, succinate, malate, fumarate.

DNA Base Composition. 52.9 moles- \% guanine plus cytosine (thermal denaturation).

Source. Hydrogen sulfide containing, extremely saline, alkaline soda lakes, small pools and upper sediment layers of salt lakes.

Holotype. Strain BN 9850 of the culture collection of the Institut für Mikrobiologie at the University of Bonn; also deposited with the German Collection of Microorganisms in Göttingen, number DSM 1059.

Acknowledgements. The authors greatfully acknowledge help and valuable discussion during this work by Prof. Y. Abd el Malek (Cairo), Prof. M. Agagg (Alexandria), Prof. N. Pfennig, Dr. K. Schmidt, Dr. H. Hippe, Dr. H. Biebl (Göttingen), Prof. K. E. Wohlfarth-Bottermann, Dr. R. Stiemerling and Mrs. B. Steil (Bonn). This work was supported in part by the Deutsche Forschungsgemeinschaft.

\section{REFERENCES}

Abd el Malek, Y., Rizk, S. G.: Bacterial sulfate reduction and the development of alkalinity. III. Experiments under natural conditions in the Wadi Natrun. J. appl. Bacteriol. 26, 20-26 (1963)

Baas Becking, L. G. M.: On organisms living in concentrated brine. Tijdschr. Nederland. Dierk. Ver., 3. Ser., 1, 6-9 (1928)

Cherni, N. E., Solovjeva, J. V., Fedorov, V. D., Kondratieva, E. N.: Ultrastructure of two species of purple sulfur bacteria. Mikrobiologiya 38, 479-484 (1969)

Drews, G., Giesbrecht, P.: Die Thylakoidstrukturen von Rhodopseudomonas spec. Arch. Mikrobiol. 52, 242-250 (1965)

Drews, G., Giesbrecht, P.: Rhodopseudomonas viridis nov. spec., ein neu isoliertes, obligat phototrophes Bakterium. Arch. Mikrobiol. 53, 255-262 (1966)
Eimhjellen, K. E., Steensland, H., Traetteberg, J.: A Thiococcus sp. nov. gen., its pigments and internal membrane system. Arch. Mikrobiol. 59, 82-92 (1967)

Eimhjellen, K. E.: Thiocapsa pfennigii sp. nov., a new species of phototrophic sulfur bacteria. Arch. Mikrobiol. 73, 193-194 (1970)

Gibbs, S. P., Sistrom, W. R., Worden, P. B.: The photosynthetic apparatus of Rhodospirillum molischianum. J. Cell. Biol. 26, $395-412(1965)$

Gloe, A., Pfennig, N., Brockmann, H., Jr., Trowitsch, W.: A new bacteriochlorophyll from brown colored Chlorobiaceae. Arch. Microbiol. 102, 103-109 (1975)

Hager, A., Stransky, H.: Das Carotinoidmuster und die Verbreitung des lichtinduzierten Xanthophyllcyclus in verschiedenen Algenklassen. I. Methoden zur Identifizierung der Pigmente. Arch. Mikrobiol. 71, 132-163 (1970)

Holt, S. C., Trüper, H. G., Takaćs, B. J.: Fine structure of Ectothiorhodospira mobilis strain 8113 thylakoids: chemical fixation and freeze-etching studies. Arch. Mikrobiol. 62, 111-128 (1968)

Jannasch, H. W.: Die bakterielle Rotfärbung der Salzseen des Wadi Natrun (Ägypten). Arch. Hydrobiol. 53, 425-433 (1957)

Jensen, L. S.: The constituion of some bacterial carotenoids and their bearing on biosynthetic problems. Kgl. Norsk. Videns, Selks. Skr. no. 8 (1962)

Keppen, O. I., Gorlenko, V. M. : A new species of purple budding bacteria containing bacteriochlorophyll b. Mikrobiologiya 44, $258-264(1975)$

Marmur, J., Doty, P.: Determination of the base composition of deoxyribonucleic acid from its thermal denaturation temperature. J. Mol. Biol. 5, 109-118 (1962)

Meyer, S. A., Schleifer, K. A. : Rapid procedure for the approximate determination of the deoxyribonucleic acid base composition of Micrococci, Staphyllococci and other bacteria. Intern. J. Syst. Bact. 25, 383-385 (1975)

Pfennig, N.: Anreicherungskulturen für rote und grüne Schwefelbakterien. Zbl. Bakt., I. Abt. Orig., Suppl. 1, 179-189, 503-504 (1965)

Pfennig, N., Trüper, H. G.: The phototrophic bacteria. In: Bergey's manual of determinative bacteriology, 8th ed. (R. E. Buchanan, N. E. Gibbons, eds.), pp. $24-64$. Baltimore: Williams and Wilkins 1974

Raymond, J. C., Sistrom, W. R.: The isolation and preliminary characterization of a halophilic photosynthetic bacterium. Arch. Mikrobiol, 59, 255-268 (1967)

Raymond, J. C., Sistrom, W. R.: Ectothiorhodospira halophila: A new species of the genus Ectothiorhodospira. Arch. Mikrobiol. 69, $121-126(1969)$

Remsen, C. C., Watson, S. W., Waterbury, J. B., Trüper, H. G.: Fine structure of Ectothiorhodospira mobilis Pelsh. J. Bacteriol. 95, 2374-2392 (1968)

Schmidt, K., Trüper, H. G.: Carotenoid composition in the genus Ectothiomodospira Pelsh. Arch. Mikrobiol. 80, 38-42 (1971)

Trüper, H. G.: Ectothiorhodospira mobilis Pelsh, a photosynthetic sulfur bacterium depositing sulfur outside the cells. J. Bacteriol. 95, 1910-1920 (1968)

Ulitzur, S : Rapid determination of DNA base composition by ultraviolet spectroscopy. Biochim. Biophys. Acta 272, 1-11 (1972)

van Niel, C. B.: On the morphology and physiology of the purple and green sulphur bacteria. Arch. Mikrobiol. 3, 1-112 (1931)

Whittenbury, R., McLee, A. G.: Rhodospeudomonas palustris and Rhodopseudomonas viridis - photosynthetic budding bacteria. Arch. Mikrobiol. 59, 324-334 (1967)

Received May 21, 1977 